\title{
Identifikasi Kebutuhan Infrastruktur Penunjang Pengembangan Pariwisata di Wilayah Perbatasan Utara Kalimantan
}

\author{
Efraim Bavo Priyana ${ }^{1}$, Eko Prihartanto*2 \\ ${ }^{1}$ Program Studi Pariwisata, Jurusan Manajemen, Universitas Terbuka \\ ${ }^{2}$ Program Studi Teknik Sipil, FT UBT, Tarakan \\ E-mail: *2eko_prihartanto@borneo.ac.id
}

Received 04 December 2020; Reviewed 04 August 2021; Accepted 24 August 2021

Journal Homepage: http://jurnal.borneo.ac.id/index.php/borneoengineering

\begin{abstract}
Tourism as a support for the economy of a region requires special attention to attract tourists both from home and abroad. Nunukan Regency as an area directly adjacent to the State of Malaysia still lacks infrastructure. The need for supporting infrastructure adds to the attractiveness of a tourist area. So to know what are the needs of tourist areas need to be done research by identifying. The research method used is descriptive statistics with respondents from Stakeholders in Nunukan Regency, data obtained by the dissemination of questionnaires and interviews. This research object is a potential tourist area as well as tourist attractions in Nunukan Regency. The results that have been obtained from this study there are 3 variables including Access, accommodation, Facilities with a total of 17 indicators. Where there are 3 invalid indicators such as the existence of roads through land transportation, the existence of places of worship, passive recreational facilities (Seating, campfires). Identification obtained with a percentage value of $85 \%$ is available facilities to enjoy the beauty of nature, this is because the dominant tourism in Nunukan Regency is Natural Beauty.
\end{abstract}

Keywords: Borders; Facilities; Infrastructure; Tourism.

\begin{abstract}
Abstrak
Pariwisata sebagai sebagai pendukung perekonomian suatu wilayah membutuhkan perhatian khusus untuk menarik wisatawan baik dari dalam maupun luar negeri. Kabupaten Nunukan sebagai wilayah yang berbatasan langsung dengan Negara Malaysia masih kurang memiliki infrastruktur. Kebutuhan akan infrastruktur penunjang menambah daya tarik dari sebuah kawasan wisata. Sehingga untuk mengetahui apa saja kebutuhan dari daerah wisata perlu dilakukan penelitian dengan melakukan identifikasi. Metode penelitian yang digunakan adalah Statistik deskriptif dengan responden dari Stakeholders di Kabupaten Nunukan, data diperoleh dengan penyebaran kuesioner dan wawancara.Objek Penelitian ini adalah wilayah berpotensi wisata serta objek wisata di Kabupaten Nunukan. Hasil dari penelitian ini menggambarkan 3 variabel dalam mendukung pengembangan infrastruktur di wilayah perbatasan Utara Kalimantan, diantaranya Akses, akomodasi, Fasilitas dengan jumlah 17 indikator. Variabel tersebut diolah sehingga menghasilkan indikator tertinggi pada setiap variabelnya seperti Adanya Jalan Alternatif menuju tempat wisata pada variabel Akses, Adanya Kamar mandi atau toilet umum bersih pada variabel Akomodasi dan Tersedia fasilitas untuk menikmati keindahan alam pada variabel Fasilitas. Dari penelitian didapatkan bahwa dominasi indikator tersebut menjadi perhatian bagi pemerintah daerah untuk diperhatikan dalam rangka memajukan pariwisata di Kabupaten Nunukan.
\end{abstract}

Kata kunci: Fasilitas; Infrastruktur; Pariwisata; Perbatasan. 


\section{Pendahuluan}

Pada umumnya pariwisata merupakan bagian dari usaha pemerintah dalam memperkenalkan kebudayaan serta kekayaan alam yang khas, baik flora atau fauna yang keseluruhan dimiliki suatu wilayah sehingga menarik untuk dikunjungi. Potensi pariwisata tak lepas dari adanya akses untuk mempermudah menuju daerah tujuan hal ini dilihat dari sasaran strategis kalimantan Utara sampai tahun 2025 dengan Produk Domestik Regional Bruto di tahun 2018 sebesar 837095 (Sekretariat Daerah Provinsi Kalimantan Utara, 2019). Pariwisata juga dapat mendongkrak pendapatan asli daerah (PAD) sehingga untuk memaksimalkannya dibutuhkan dukungan dari Stakeholders (pemangku kepentingan) untuk menunjang wilayah yang berpotensi wisata. Sarana dan prasarana sebagai infrastruktur diharapkan menunjang segala kemudahan untuk menarik pariwisata. Dalam kegiatan kepariwisataan ada beberapa pihak yang memiliki peran dan terlibat langsung dalam kegiatan kepariwisataan (Rahayu, Dewi and Fitriana, 2016). Menurut Giyarsih (2014) penyebab kemiskinan di Kabupaten Nunukan adalah minimnya/kurangnya natural assets, human assets, physical assets, financial assets, dan social assets. sehingga berdasarkan hal tersebut maka diperlukan startegi guna mempercepat pengentasan kemiskinan di Kabupaten Nunukan. Pariwisata membutuhkan sarana dan prasarana dalam mempermudah pengunjung untuk mendapatkan layanan baik barang ataupun jasa, penelitian ini sebagai penelitian awal untuk melakukan identifikasi apa saja infrastruktur yang dibutuhkan di Wilayah Utara perbatasan Kalimantan dalam penelitian ini adalah Kabupaten Nunukan.

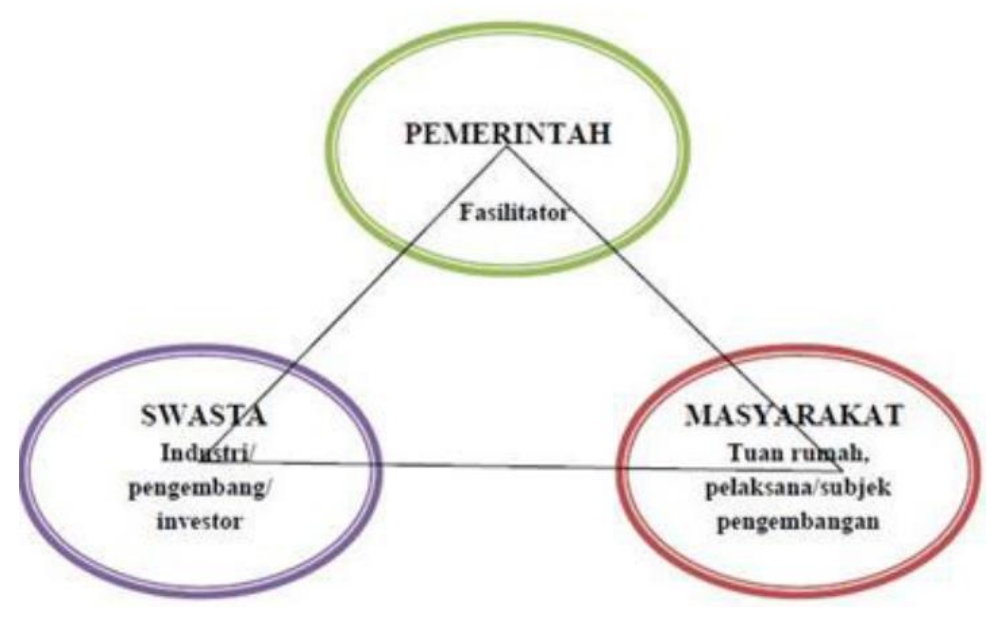

Gambar 1. Pemangku Kepentingan dalam Pariwisata (Sunaryo, 2013)

Menurut undang-undang No.9 tahun 1990 pasal 1 tentang kepariwisataan, Pariwisata adalah segala sesuatu yang berhubungan dengan wisata, termasuk pengusahaan objek dan daya tarik wisata serta usaha-usaha yang terkait dibidang tersebut. Kepariwisataan menurut Tap MPRS tahun 1960 adalah suatu cara untuk memenuhi kebutuhan manusia dalam memberikan hiburan rohani dan jasmani, setelah beberapa waktu bekerja serta mempunyai modal untuk melihat-lihat daerah lain (wisatawan nusantara) atau negara-negara lain (wisatawan mancanegara).

Daerah perbatasan dibagian utara Kalimantan, memiliki banyak daerah berpotensi wisata. Hal ini sebagai keunikan sendiri, melihat adanya keunikan 2 (dua) negara mulai dari kebudayaan, peraturan sampai dengan kehidupan sehari-hari masyarakatnya, adapun penelitian terdahulu yang dilakukan oleh Mubarak (2021) memiliki tujuan untuk mengidentifikasi dan menganalisa ketersediaan infrastruktur sosial dan infrastruktur ekonomi serta kondisi sosial ekonomi masyarakat di Kabupaten Nunukan selama tahun 2015 hingga 2019. Sari (2019) mengungkapkan mengenai manfaat yang 
dapat diperoleh dari pembangunan infrastruktur di daerah perbatasan bagi masyarakat yaitu membantu masyarakat dengan adanya konstruksi sipil yang membantu pemenuhan kebutuhan hidup, meningkatkan ekonomi masyarakat perbatasan dan kemudahan dalam akses Sehingga pada penelitian ini lebih fokus pada kebutuhan infratruktur untuk pengembangan pariwisata. Prasetya (2013) menambahkan bahwa Pengembangan infrastruktur yang tepat dan karakter yang sesuai dengan wilayah perbatasan darat dapat berdampak pada percepatan pembangunan ekonomi, sehingga meningkatkan daya saing dan mengarah pada peningkatan kesejahteraan sosial. Lintas negara ini dapat menguntungkan, karena dapat menarik wisatawan dari luar negeri untuk berkunjung ke Indonesia. Hal ini karena kalimantan Utara berbatasan langsung dengan Negara Malaysia (Kementerian Sekretariat Negara Republik Indonesia, 2012).

Berdasarkan latarbelakang masalah diatas sehingga dilakukan penelitian dengan tujuan untuk melakukan Identifikasi terhadap Variabel dan Indikator kebutuhan Sarana dan Prasarana yang mendukung pengembangan pariwisata yang berada di wilayah perbatasan Utara Kalimantan.

\section{Tinjauan Pustaka}

\subsection{Pariwisata}

Menurut Ismayanti (2010) Pariwisata adalah kegiatan dinamis yang melibatkan banyak manusia serta menghidupkan berbagai bidang usaha. Industri pariwisata adalah kumpulan usaha pariwisata yang saling terkait dalam menghasilkan barang/jasa bagi pemenuhan kebutuhan wisatawan pada penyelenggaraan pariwisata (Tapatfeto, Bessie and Kasim, 2018)

\subsection{Strategi Pengembangan Wisata}

Perumusan strategi adalah pengembangan rencana panjang untuk manajemen efektif dari kesempatan dan ancaman lingkungan, dilihat dari kekuatan dan kelemahan organisasi. Perumusan strategi meliputi menentukan misi organisasi, menentukan tujuan-tujuan yang ingin dicapai, pengembangan strategi dan penetapan pedoman kebijakan (Hunger, 2003).

\subsection{Tahap Pengembangan Wisata}

Pada umumnya pengembangan pariwisata selalu mengikuti siklus hidup pariwisata sehingga dapat menentukan posisi pariwisata yang akan dikembangkan. Cooper (1997), tahapan tersebut terdiri dari:

1. Tahap Eksplorasi (exploration) yang berkaitan dengan discovery yaitu suatu tempat sebagai potensi wisata baru ditemukan oleh wisatawan, pelaku pariwisata, maupun pemerintah. Biasanya jumlah kunjungan sedikit, wisatawan tertarik pada daerah yang belum tercemar dan sepi, lokasi sulit dicapai namun diminati oleh sejumlah kecil wisatawan yang justru menjadi berminat karena belum ramai dikunjungi.

2. Tahap Keterlibatan (involvement) yang diikuti oleh kontrol lokal, di mana biasanya oleh masyarakat lokal. Pada tahap ini terdapat inisiatif dari masyarakat lokal, obyek wisata mulai dipromosikan oleh wisatawan, jumlah wisatawan meningkat, dan infrastruktur mulai dibangun.

3. Tahap Pengembangan (development) dengan adanya kontrol lokal menunjukan adanya peningkatan jumlah kunjungan wisatawan secara drastis. Pengawasan oleh lembaga lokal agak sulit membuahkan hasil, masuknya industri wisata dari luar dan kepopuleran kawasan wisata menyebabkan kerusakan lingkungan alam dan sosial nasional.

4. Tahap Konsolidasi (consolidation) ini ditunjukan oleh penurunan tingkat pertumbuhan kunjungan wisatawan. Kawasan wisata dipenuhi oleh berbagai industri pariwisata berupa hiburan dan berbagai macam atraksi wisata.

5. Tahap Kestabilan (stagnation) jumlah wisatawan tertinggi telah dicapai dan kawasan ini mulai ditinggalkan karena tidak mode lagi, kunjungan ulang dan para pebisnis memanfaatkan fasilitas 
yang ada. Pada tahapan ini terdapat upaya untuk menjaga jumlah wisatawan secara intensif dilakukan oleh industri pariwisata dan kawasan ini kemungkinan besar mengalami masalah besar yang terkait lingkungan alam maupun sosial budaya.

6. Tahap Penurunan Kualitas (decline) Hampir semua wisatawan telah mengalihkan kunjungannya ke daerah tujuan wisata lain. Kawasan ini telah menjadi obyek wisata kecil yang dikunjungi sehari atau akhir pekan. Beberapa fasilitas pariwisata telah diubah bentuk dan fungsinya menjadi tujuan lain. Dengan demikian pada tahap ini diperlukan upaya pemerintah untuk meremajakan kembali.

7. Tahap Peremajaan Kembali (rejuvenate) di mana dalam tahap ini perlu dilakukan pertimbangan mengubah pemanfaatan kawasan pariwisata menjadi pasar baru, membuat saluran pemasaran baru, dan mereposisi atraksi wisata kebentuk lain. Oleh sebab itu diperlukan modal baru atau kerjasama antara pemerintah dengan pihak swasta.

Dari setiap tahapan akan dilakukan penyesuaian, apakah dapat sesuai dengan kebutuhan wilayah tersebut. Dari setiap tahapan penyesuaian dilakukan untuk memperoleh peluang pengembangan dari pariwisata.

\subsection{Faktor Pendukung Pengembangan Objek wisata}

Menurut Soekadijo dalam Pradikta (2013) ada tiga modal atraksi yang dapat menarik kedatangan wisatawan diantaranya ;

1. Modal dan Potensi Alam Alam merupakan salah satu faktor pendukung seorang melakukan perjalanan wisata karena ada orang berwisata hanya sekedar menikmati keindahan alam, ketenangan alam, serta ingin menikmati keaslian fisik, flora dan faunanya.

2. Modal dan Potensi Kebudayaannnya Yang dimaksud potensi kebudayaan disini merupakan kebudayaan dalam arti luas bukan hanya meliputi seperti kesenian atau kehidupan kerajinan dll. Akan tetapi meliputi adat istiadat dan segala kebiasaan yang hidup di tengah-tengah kehidupan masyarakat. Sehingga diharapkan wisatawan atau pengunjung bisa tertahan dan dapat menghabiskan waktu di tengah-tengah masyarakat dengan kebudayaannya yang menghabiskan waktu di tengah-tengah masyarakat dengan kebudayaannya yang dianggap menarik.

3. Modal dan Potensi Manusia Manusia dapat dijadikan atraksi wisata yang berupa keunikankeunikan adat istiadat maupun kehidupannya namun jangan sampai martabat dari manusia tersebut direndahkan sehingga kehilangan martabatnya sebagai manusia. Agar dapat mengidentifikasi faktor pendukung dengan jelas maka akan dijabarkan

Dari semua faktor yang telah dijelaskan diatas sehingga secara garis besar dapat diperoleh dua elemen yaitu: kekuatan dan peluang (Pearce 2008).

\subsection{Faktor Pendukung Pengembangan Objek wisata}

Faktor Penghambat Pengembangan Obyek Wisata menurut Heri (2011), pengembangan obyek wisata pasti tidak terlepas dari faktor-faktor penghambat seperti berikut ini:

1. Kurangnya peran serta masyarakat dalam sektor pariwisata

2. Kurangnya prioritas pembangunan pemerintah kabupaten terhadap sektor pariwisata

3. Kurangnya kuantitas dan spesialisasi sumber daya manusia pada Dinas terkait

4. Kurangnya kerja sama dengan investor

5. Belum terdapat sistem promosi yang menarik

6. Keterbatasan sarana dan prasarana kerja pada dinas terkait dan objek wisata

7. Keterbatasan dan kurangnya perawatan fasilitas penunjang objek wisata. 


\subsection{Infrastruktur Pariwisata}

Infrastruktur pariwisata dapat dianggap sebagai elemen fisik yang dirancang dan dibangun untuk memenuhi kebutuhan pengunjung (Jovanović, 2016). Hubungan yang kuat antara pengembangan pariwisata dan infrastruktur telah secara teoritis dibangun oleh sejumlah penulis (Adebayo, Iweka, 2014). Infrastruktur pariwisata adalah dasar dari pengembangan pariwisata, juga sebagai dasar untuk pemanfaatan tujuan sumber daya. Pentingnya infrastruktur pariwisata tercermin dalam kenyataan bahwa infrastruktur tersebut dapat berkontribusi pada peningkatan efisiensi produksi dan distribusi layanan pariwisata, dan, dalam beberapa kasus, seperti destinasi terpencil, bahkan meningkatkan pasokan layanan pariwisata. Bagi wisatawan untuk dapat mencapai beberapa tujuan wisata, harus ada infrastruktur transportasi yang dikembangkan, yang merupakan prasyarat untuk mengkonsumsi layanan wisata lainnya dari destinasi itu sendiri. Kedatangan wisatawan meningkatkan efisiensi sumber daya manusia di tempat tujuan, karena wisatawan memerlukan layanan tertentu agar merasa lebih baik selama mereka tinggal di tempat tujuan wisata yang dipilih. Secara khusus, ada peningkatan permintaan untuk layanan infrastruktur dalam hal pasokan air, pembuangan limbah, komunikasi dan pasokan listrik, sebagai elemen yang diperlukan untuk kenyamanan fungsi wisatawan di tujuan yang dipilih. Infrastruktur didefinisikan sebagai penyediaan keselamatan publik, layanan transportasi, sistem medis, sistem keuangan, sistem pendidikan, dan layanan lain yang terlibat dalam populasi, serta dalam permintaan wisatawan (Ritchie, Crouch 2005). Sebagai komponen dari produk pariwisata regional, infrastruktur pariwisata sangat penting bagi pertumbuhan pariwisata jangka panjang dan kemajuan umum tujuan wisata dalam menyediakan layanan yang diperlukan untuk wisatawan.

\section{Metode Penelitian}

\subsection{Lokasi}

Penelitian ini dilaksanakan di Kabupaten Nunukan Kalimantan Utara. Penelitian ini menggunakan metode penelitian kualitatif dengan pendekatan studi kasus. Dengan menggunakan jenis penelitian studi kasus, penelitian ini bermaksud untuk memberikan uraian mengenai Pengembangan Pariwisata yang di dukung oleh Infrastruktur penunjang. Dalam penelitian ini akan dijelaskan secara umum mengenai potensi pariwisata secara khusus akan menguraikan mengenai potensi wisata yang terdapat di Propinsi Kalimantan Utara.

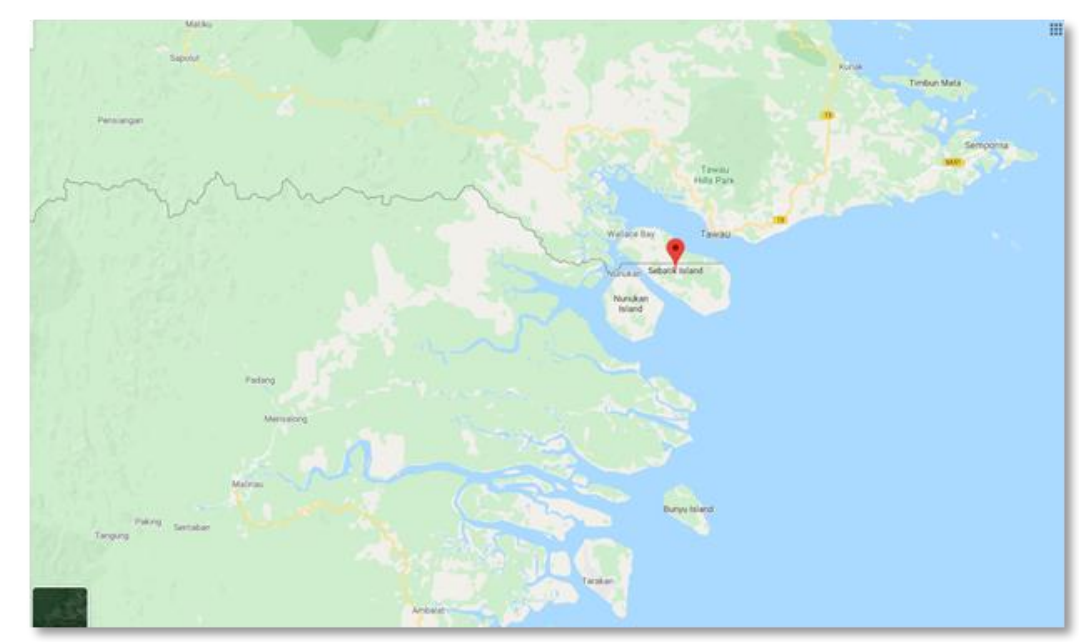

Gambar 2. Wilayah Sebatik di Kabupaten Nunukan berbatasan darat dan laut langsung dengan negara bagian Sabah, Malaysia 


\subsection{Objek Penelitian}

Objek Penelitian ini adalah wilayah berpotensi wisata serta objek wisata di Propinsi Kalimantan Utara sebagai wilayah perbatasan antara negara Indonesia-Malaysia. wilayah yakni Sebatik berada pada Kabupaten Nunukan sama-sama berbatasan langsung dengan Malaysia, baik wilayah daratan dan perairan (laut). Wilayah inilah yang peneliti anggap memiliki daya tarik, baik alam maupun budaya lokal yang dapat berdaya saing apabila pengembangan pariwisata optimal.

\subsection{Teknik Pengambilan Informan Peneliti}

Teknik sampling yang digunakan dalam penelitian ini yaitu purposive sampling. Sedangkan teknik pengumpulan data yang digunakan yaitu dengan observasi, wawancara dan dokumentasi. penelitian akan membandingkan hasil pengamatan dengan hasil wawancara, kemudian membandingkan hasil wawancara dengan dokumen yang terkait dengan tema penelitian.

\subsection{Metode Pengumpulan Data}

1. Data Primer

Data primer diperoleh dengan :

a. Kuesioner

b. Wawancara

2. Data Sekunder

Data yang dikumpulkan oleh peneliti dari sumber diluar data primer, meliputi artikel, dan laporan dari situs-situs resmi yang dapat dipertanggungjawabkan keakuratannya yang terkait dengan penelitian.

3. Responden

Adapun responden dari penelitian ini adalah

a. Pemerintah daerah Kabupaten Nunukan seperti:

1) Badan Perencanaan Pembangunan Daerah

2) Dinas Pekerjaan Umum, Penataan Ruang, Perumahan dan Kawasan Pemukiman.

3) Dinas Pariwisata, Kepemudaan Dan Olahraga

b. Pelaku usaha bidang Pariwisata di Kabupaten Nunukan Seperti:

1) Hotel

2) Biro pelayanan travel

3) Penyedia jasa angkutan Laut

\subsection{Metode Analisis Data}

Data yang telah diperoleh baik data primer dan sekunder selanjutnya akan di analisis dengan melakukan tahapan atau prosedur reduksi data, klasifikasi data, Pembahasan sampai kesimpulan. Sehingga diperoleh Infrastruktur Penunjang untuk meningkatkan pengembangan pariwisata di wilayah Utara Kalimantan. Hasil pada pembahasan berikut telah melalui uji validasi dan reabilitas, adapun prosesnya dijelaskan di Pembahasan.

\section{Pembahasan}

\subsection{Proses Identifikasi terhadap kebutuhan Infrastruktur di wilayah Kabupaten Nunukan}

Adapun hasil yang telah dilaksanakan adalah sebagai berikut :

\subsubsection{Menentukan Validasi dan reabilitas data}

Suatu skala atau instrumen pengukur dapat dikatakan mempunyai validitas yang tinggi apabila instrumen tersebut menjalankan fungsi ukurnya, atau memberikan hasil ukur yang sesuai dengan 
maksud dilakukannya pengukuran tersebut. Sedangkan tes yang memiliki validitas rendah akan menghasilkan data yang tidak relevan dengan tujuan pengukuran.

Uji Validitas berguna untuk mengetahui kevalidan atau kesesuaian kuesioner yang digunakan oleh peneliti dalam mengukur dan memperoleh data penelitian dari para responden.Tabel 1 Berikut adalah variabel yang dijadikan pernyataan pada kuesioner

Tabel 1. Variabel pada sarana dan prasarana

\begin{tabular}{lll}
\hline No. & Variabel & Indikator \\
\hline 1 & Akses & Adanya jalan yang dilalui transportasi darat \\
2 & & Adanya Jalan Alternatif menuju tempat wisata \\
3 & & Tempat Parkir tersedia untuk segala jenis kendaraan \\
4 & & Adanya Pelayanan parkir di tempat wisata \\
5 & & tentang Harga Parkir terjangkau \\
6 & Akomodasi & Adanya penginapan di lokasi wisata \\
7 & & Harga penginapan yang terjangkau \\
8 & & Adanya tempat belanja souvenir dan oleh-oleh \\
9 & & Adanya tempat ibadah \\
10 & & Adanya tempat makan di lokasi wisata \\
11 & & Adanya Kamar mandi atau toilet umum bersih \\
12 & Fasilitas & Tersedia fasilitas untuk menikmati keindahan alam \\
13 & & Tersedia fasilitas rekreasi pasif (Tempat duduk, api unggun) \\
14 & & Tersedia fasilitas rekreasi aktif (tempat memancing, taman bermain anak, tempat \\
& & outbound) \\
15 & Tersedianya Jenis-jenis sambungan/telekomunikasi (Telepon, sms, dan internet) \\
16 & & Tersedianya angkutan umum \\
17 & Tersedianya Jenis fasilitas yang sudah di sediakan untuk tempat menginap bagi \\
& para pengunjung \\
\hline
\end{tabular}

Pembagian Nilai $r$ hitung dengan $r$ table :

Jika nilai $\mathrm{r}$ hitung $>r$ table $=$ valid

Jika nilai $r$ hitung $<r$ table $=$ tidak valid

Sebelum mengolah data pada SPSS terlebih dahulu masukkan data. Setelah data yang telah dimasukkan tersebut, selanjutnya adalah memasukkan data untuk diolah ke SPSS untuk mengetahui kevalidan data yang ada, Nilai $\mathrm{r}$ table dengan $\mathrm{N}=40$ (untuk nelayan) pada signifikansi $5 \%$ pada distribusi $r$ tablestatistic, maka diperoleh nilai $r$ table sebesar 0,312. Dan uji Reabilitas untuk Alpha= 0,846. sehingga didapatkan pada Tabel 2 berikut :

\section{Tabel 2. Rekapitulasi dan Reabilitas}

\begin{tabular}{lll}
\hline No. & \multicolumn{1}{c}{ Variabel } & \\
\hline 1 & & \multicolumn{1}{c}{ Indikator } \\
2 & \multirow{2}{*}{ Adanya Jalan Alternatif menuju tempat wisata } \\
3 & & Tempat Parkir tersedia untuk segala jenis kendaraan \\
4 & & Adanya Pelayanan parkir di tempat wisata \\
5 & & tentang Harga Parkir terjangkau \\
6 & & Adanya penginapan di lokasi wisata \\
7 & Akomodasi & Harga penginapan yang terjangkau \\
8 & & Adanya tempat belanja souvenir dan oleh-oleh \\
9 & & Adanya tempat makan di lokasi wisata \\
10 & & Adanya Kamar mandi atau toilet umum bersih \\
11 & & Tersedia fasilitas untuk menikmati keindahan alam \\
& & Tersedia fasilitas rekreasi aktif (tempat memancing, taman bermain \\
12 & Fasilitas & anak, tempat outbound) \\
13 & & Tersedianya Jenis-jenis sambungan/telekomunikasi \\
14 & & Tersedianya angkutan umum \\
& & Tersedianya Jenis fasilitas yang sudah di sediakan untuk tempat \\
\hline
\end{tabular}


Dari proses validasi dan reabilitas didapatkan variabel yang merupakan pernyataan pada kuesioner terdapat 14 indikator yang valid dari 17 Indikator pada 3 variabel. Dan pada kuesioner tersebut dapat dinyatakan ajeg karena reliabel. Selanjutnya, dari kuesioner yang telah melalui proses analisis dilakukan interpretasi dengan Cara untuk mendapatkan besaran persentasi pada kriteria dengan membagi pernyataan menjadi Variabel-variabel tersebut yang sudah dikelompokkan tiap Variabelnya kemudian dilakukan skoring menggunakan Skala Likert dalam bentuk kuesioner tingkat kepentingan dan dibagikan kepada responden di wilayah penelitian. berdasarkan pernyataan tersebut didapat hasil berupa rekapitulasi dalam bentuk diagram seperti pada gambar 3,

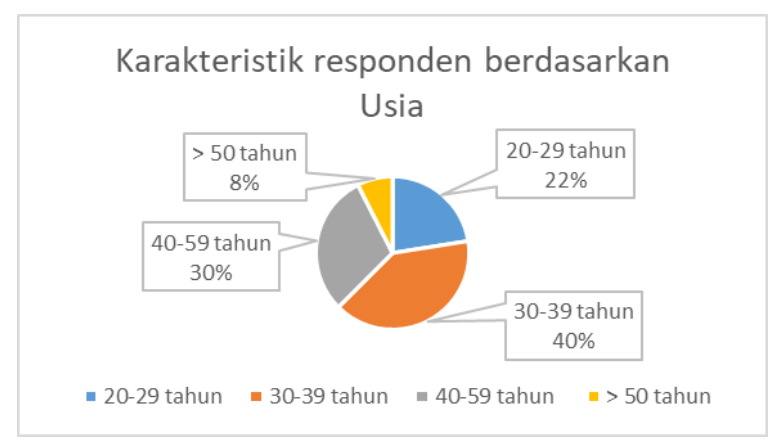

Gambar 3. Usia Responden

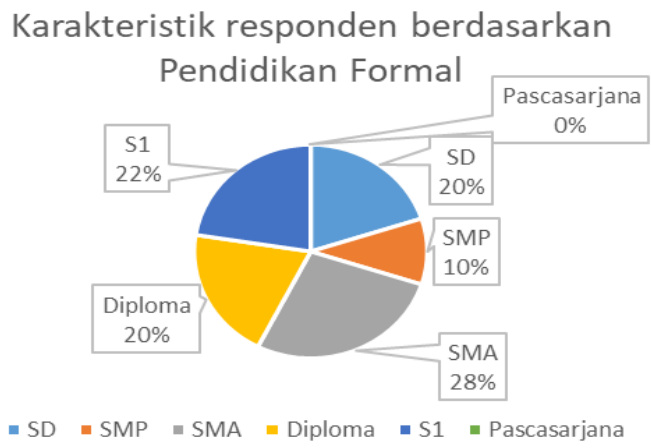

Gambar 5. Pendidikan Formal Responden

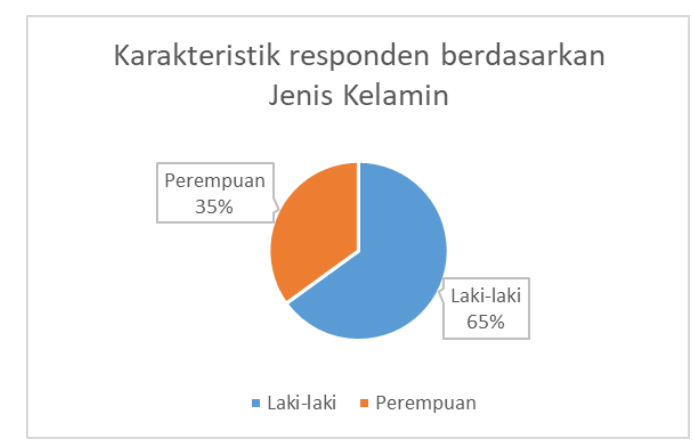

Gambar 4. Jenis Kelamin Responden

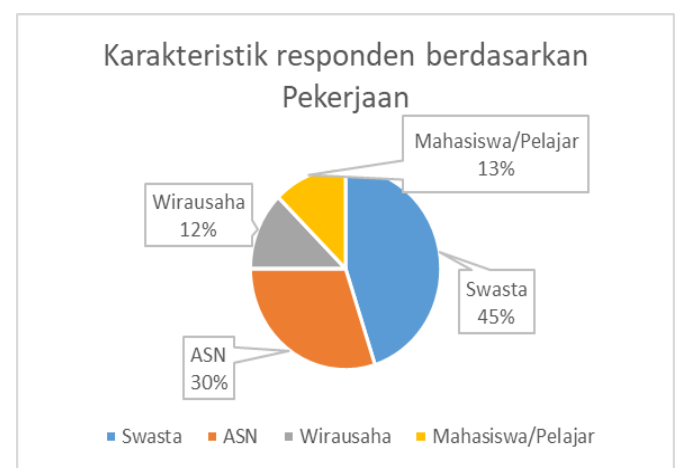

Gambar 6. Pekerjaan Responden

\subsection{Interpretasi}

- Interpretasi pada variabel Akses : Pada wilayah wisata di Kabupaten Nunukan sangat dibutuhkan jalan alternatif yang dapat dilewati berbagai alat transportasi dengan waktu tempuh singkat, dimana warga menginginkan semua akses kemudahan dalam menuju tempat wisata sehingga dimudahkan dalam menuju ke tempat tujuan bersama keluarga. Di lokasi wisata dari perspektif Stakeholders akan dikelola oleh pemerintah daerah agar tertata rapi bersama warga setempat untuk menyediakan lahan parkir yang efektif dan dapat memberikan pemasukan pada Pendapatan Asli Daerah Kabupaten Nunukan serta meningkatkan pendapatan warga di lokasi wisata. Harga retribusi parkir nantinya akan merujuk pada peraturan Pemerintah Daerah Nunukan agar sesuai standar dan tidak memberatkan masyarakat.

- Interpretasi pada variabel Akomodasi : Dari hasil wawancara terhadap responden masyarakat, dominan menginginkan adanya penginapan di lokasi wisata khususnya untuk wisata pantai dan wisata yang memiki jarak tempuh jauh. Harga penginapan di wisata lokasi pun diharapkan dapat dijangkau masyarakat sehingga dapat menarik lebih banyak pengunjung. Seperti umunya objek wisata lainnya diharapkan adanya toko yang menjual 
souvenir dan oleh-oleh sebagai buah tangan untuk kerabat dan keluarga, serta sebagai tanda kenangan jika pernah berkunjung ke wilayah wisata tersebut. Disamping itu untuk objek wisata juga diharapkan memiliki restoran atau rumah makan yang menyediakan hidangan khas daerah wisata sebagai bagian dari tujuan dari pengunjung. Disisi lain masyarakat menginginkan untuk objek wisata yang minim dengan bagian akomodasi disediakan sarana toilet yang bersih dan untuk wisata pantai disediakan kamar mandi umum yang bersih. Potensi wisata akan jauh lebih mendatangkan pengunjung jika tersedia variabel akomodasi ini.

- Interpretasi pada variabel Fasilitas : dari penelitian ini didapat bahwa masyarakat menginginkan di setiap wilayah yang terdapat objek wisata di kabupaten Nunukan terdapat fasilitas untuk menikmati keindahan alam, selain untuk melihat pemandangan juga dapat untuk mengabadikan momen. Fasilitas untuk keluarga atau komunitas juga diharapkan ada seperti tempat memancing, taman bermain anak, tempat outbound dimana akan menjadi nilai tambah objek wisata untuk dapat sering dikunjungi dalam jumlah pengunjung lebih dari 1 orang. Fasilitas yang tak kalah penting adalah adanya jaringan komunikasi untuk komunikasi terlebih lagi pengunjung yang hobi swafoto untuk melakukan unggah foto di media sosial, hal ni secara tidak langsung dapat membantu memperkenalkan objek wisata secara virtual dan sebagai pengenalan akan suatu daerah. Fasilitas untuk pengunjung dari luar Kabupaten Nunukan harus juga menjadi perhatian seperti Tersedianya angkutan umum dan Tersedianya Jenis fasilitas yang sudah di sediakan untuk tempat menginap bagi para pengunjung sehingga lebih memudahkan untuk menikmati objek wisata.

Tabel 3. Presentase pada Respon

\begin{tabular}{|c|c|c|c|c|c|c|c|}
\hline \multirow{2}{*}{ No } & \multirow{2}{*}{ Variabel } & \multirow{2}{*}{ Indikator } & \multicolumn{5}{|c|}{ Respon (\%) } \\
\hline & & & STS & TS & $\mathbf{N}$ & $\mathbf{S}$ & SS \\
\hline 1 & Akses & Adanya Jalan Alternatif menuju tempat wisata & 0 & 0 & 5 & 25 & 70 \\
\hline 2 & & $\begin{array}{l}\text { Tempat Parkir tersedia untuk segala jenis } \\
\text { kendaraan }\end{array}$ & 0 & 0 & 7,5 & 25 & 67,5 \\
\hline 3 & & Adanya Pelayanan parkir di tempat wisata & 0 & 2,5 & 10 & 25 & 62,5 \\
\hline 4 & & Harga Parkir terjangkau & 5 & 0 & 2,5 & 17,5 & 75 \\
\hline 5 & Akomodasi & Adanya penginapan di lokasi wisata & 0 & 0 & 17,5 & 32,5 & 50 \\
\hline 6 & & Harga penginapan yang terjangkau & 2,5 & 0 & 10 & 32,5 & 55 \\
\hline 7 & & Adanya tempat belanja souvenir dan oleh-oleh & 0 & 0 & 2,5 & 37,5 & 60 \\
\hline 8 & & Adanya tempat makan di lokasi wisata & 0 & 0 & 2,5 & 37,5 & 60 \\
\hline 9 & & Adanya Kamar mandi atau toilet umum bersih & 0 & 0 & 2,5 & 22,5 & 75 \\
\hline 10 & Fasilitas & $\begin{array}{l}\text { Tersedia fasilitas untuk menikmati keindahan } \\
\text { alam }\end{array}$ & 0 & 0 & 0 & 15 & 85 \\
\hline 11 & & $\begin{array}{l}\text { Tersedia fasilitas rekreasi aktif (tempat } \\
\text { memancing, taman bermain anak, tempat } \\
\text { outbound) }\end{array}$ & 0 & 0 & 5 & 32,5 & 62,5 \\
\hline 12 & & $\begin{array}{l}\text { Tersedianya Jenis-jenis } \\
\text { sambungan/telekomunikasi (Telepon, sms, dan } \\
\text { internet) }\end{array}$ & 0 & 0 & 7,5 & 20 & 72,5 \\
\hline 13 & & Tersedianya angkutan umum & 0 & 0 & 10 & 22,5 & 67,5 \\
\hline 14 & & $\begin{array}{l}\text { Tersedianya Jenis fasilitas yang sudah di } \\
\text { sediakan untuk tempat menginap bagi para } \\
\text { pengunjung }\end{array}$ & 0 & 0 & 7,5 & 32,5 & 60 \\
\hline
\end{tabular}




\section{Kesimpulan}

Penelitian ini telah didapatkan hasil identifikasi seperti variabel dengan indikator Akses didapat indikator harga parkir terjangkau, pada variabel Akomodasi didapat indikator Adanya Kamar mandi atau toilet umum bersih, dan untuk pada variabel Fasilitas dengan indikator tersedianya fasilitas untuk menikmati keindahan alam. Dari 3 variabel dominan tersebut didapat kesimpulan sebagai kebutuhan infrastruktur yang dibutuhkan dalam pengembangan pariwisata do wilayah perbatasan Utara Kalimantan dalam hal ini Pemerintah Daerah Kabupaten Nunukan.

\section{Ucapan Terima Kasih}

Terima Kasih diucapkan kepada Universitas Terbuka atas pembiayaan dalam skema Penelitian dasar sampai dapat terselenggaranya penelitian ini di wilayah perbatasan utara Kalimantan, dan kepada Pemerintah Kabupaten Nunukan beserta warganya atas bantuan serta partisipasinya.

\section{Daftar Pustaka}

Adebayo, A K. And Iweka, O. (2014) 'Optimizing the Sustainability of Tourism Infrastructure in Nigeria through Design for Deconstruction Framework', American Journal of Tourism Management, 3(1A), pp. 13-19.

Cooper, Chris and Stephen Jackson. 1997. Destination Life Cycle: The Isle Of Man Case Study. In:Lesley France The Earthscan Reader In Sustainable Tourism. Uk: Earthscan Publication Limited

Giyarsih, S.R. (2014). Pengentasan Kemiskinan yang Komprehensif di Bagian Wilayah Terluar Indonesia - Kasus Kabupaten Nunukan, Provinsi Kalimantan Utara. Jurnal Manusia dan Lingkungan, 21(2), 239-246. https://doi.org/10.22146/jml.18549

Heri, Larasati. 2011. Strategi Pengembangan Pariwisata Kabupaten Pati.. Jurnal Universitas Diponegoro

Hunger, J David dan Thomas L Wheelen. 2001. Manajemen Strategis. Yogyakarta: Andi Offset

Ismayanti. 2010. Pengantar Pariwisata. Jakarta: PT.Gramedia Widiasarana Indonesia.

Jovanović, S. (2016) 'Infrastructure As Important Determinant Of Tourism Development In The Countries Of Southeast Europe', Ecoforum, 5(1), pp. 288-294.

Kementerian Sekretariat Negara Republik Indonesia (2012) Tentang Pembentukan Provinsi Kalimantan Utara. Indonesia: Prsiden Republik Indonesia.

Rahayu, S., Dewi, U. and Fitriana, K. N. (2016) 'Pengembangan Community Based Tourism Sebagai Strategi Pemberdayaan Ekonomi Masyarakat Di Kabupaten Kulon Progo, Daerah Istimewa Yogyakarta', Jurnal Penelitian HUmaniora, 21(3), pp. 1-13.

Mubarak, M., Miftah. (2021) 'Evaluasi Ketersediaan Infrastruktur Pada Kawasan Perbatasan Indonesia-Malaysia (Kasus Kabupaten Nunukan), Indonesian Journal of Spatial Planning , 2(1), pp.45-53.

Pradikta .R (2013) Strategi Pengembangan Objek Wisata Waduk Gunungrowo Indah Dalam Upaya Meningkatkan Pendapatan Asli Daerah. Skripsi Fakultas Ekonomi Universitas Negeri Semarang 
Prasetyo, B.A., Priyarsono, D.S., \& Mulatsih, S. (2013). Infrastructure, economic growth and inequality in Indonesia land borders. Economic Journal of Emerging Markets, 5(2), 99-108. https://doi.org/10.20885/ejem.vol5.iss2.art 3

Pearch, Robinson. 2008. Manajamen strategis (formulasi, implementasi, dan pengendalian). Jakarta: Salemba Empat

Sari, U. C., \& Rahman, B. (2019). Studi Literatur: Kajian Geoteknik Daerah Perbatasan sebagai Salah Satu Faktor dalam Penguatan Infrastruktur Daerah Perbatasan di Kabupaten Belu, Nusa Tenggara Timur. Jurnal Planologi, 16(1), 32. https://doi.org/10.30659/jpsa.v16i1.4320

Sekretariat Daerah Provinsi Kalimantan Utara (2019) Rencana Induk Pembangunan Kepariwisataan Provinsi Kalimantan Utara Tahun 2019-2025. Indonesia: Gubernur Kalimantan Utara.

Tapatfeto, M. A. K., Bessie, J. L. D. and Kasim, A. (2018) 'Strategi Pengembangan Objek Wisata Dalam Upaya Peningkatan Kunjungan ( Studi Pada Objek Wisata Pantai Oetune Kabupaten TTS', Journal of Management, (December), pp. 1-20. 
